\title{
Genre, Occasion, and Choral Mimesis Revisited, with Special Reference to the "Newest Sappho"*
}

\author{
Gregory Nagy
}

\section{Introduction}

This essay is the third part of a tripartite project. The first part, "Genre and Occasion," was published in Mètis (1994-1995), and the second part, "Transmission of Archaic Greek Sympotic Songs: From Lesbos to Alexandria," was published ten years later in Critical Inquiry (2004). Eleven years still later, I delivered the present essay, "Genre, Occasion, and Choral Mimesis Revisited," as a keynote lecture at the University of California, Berkeley, on the occasion of the conference on which this volume is based.

The subtitle of my essay refers to the "newest Sappho," by which I mean the new fragments of Sappho as published in a 2016 book edited by Anton Bierl and André Lardinois, The Newest Sappho (P. Obbink and P. GC Inv. 105, frs. 15 ). This book contains not only the new fragments of Sappho as edited by Dirk Obbink but also a set of chapters that comment extensively on those fragments. I focus here on two of those chapters in that book: (1) chapter 11 by Leslie Kurke, "Gendered Spheres and Mythic Models in Sappho's Brothers Poem," and (2) chapter 21 by myself, "A Poetics of Sisterly Affect in the Brothers Song and in Other Songs of Sappho."

My essay here, just like my keynote lecture as indicated above, is dedicated to two people named Leslie/Lesley. I start with the first of the two, my friend Leslie Kurke. I focus on her interpretation of a song that is part of the new set of Sappho fragments that I already mentioned. In this Sappho fragment, containing a large part of a text now known as the Brothers Song, we read near the beginning that a female speaker, evidently the character of Sappho, is in the process of speaking to someone. In chapter 11 of the book that I also already mentioned, The Newest Sappho, Kurke argues that this someone to whom Sappho is speaking is Sappho's mother. This reading meshes with that of Dirk Obbink in

* This essay was preliminarily published online in Classical Inquiries (October 1, 2015), http:// classical-inquiries.chs.harvard.edu/genre-occasion-and-choral-mimesis-revisited-with-

special-reference-to-the-newest-sappho/. 
chapter 2 of the same book. ${ }^{1}$ I am quite persuaded by Kurke's argument, though my own argument here will be slightly different from hers.

Let me draw attention to a detail. I started speaking above about the character of Sappho. One reason for my referring to Sappho this way is that, as I argue in chapter 21 of the book The Newest Sappho, the name of Sappho actually means "sister." Linguists call this kind of name a nomen loquens or "speaking name," which is a form of identification where a given person is named after a primary characteristic of that person. In various regions of the United States, for example, women are given the name Sissy or even Sister. But there is also a deeper reason for my speaking about the character of Sappho, not simply about Sappho. It is because the speaking persona of Sappho is a mimetic speaker.

The word mimetic comes from the ancient Greek concept of mimesis, which I define as meaning primarily "reenactment" and secondarily "imitation." We may also translate this word as "representation," in the sense that any imitation of an original something or someone can be seen as a representation of that something or someone. I argue, then, that the speaking done by Sappho in her songs is achieved by way of a process that I call mimesis in the title of this chapter. In terms of my argument - and I cannot emphasize this enough — the name of Sappho meant "sister" not necessarily because (1) she was a historical person who was simply named that way or because (2) she was a fictitious sister-a character of "fiction" who was created by her own songs. Rather, Sappho meant "sister" primarily because her identity was reenacted and kept on being reenacted by way of the singing and the dancing performed on festive occasions by the girls and the women of the island of Lesbos.

I just said girls and women, not just girls, and we will see later on why I said it this way. These girls and these women, as we will also see, are bonded together on festive occasions by way of a system of social grouping that is known in ancient Greek as the choros. This word is usually translated as "chorus," but such a translation can be misleading, since the modern word "chorus" is ordinarily understood to mean simply a group that sings. By contrast, the Greek term refers to a group that dances as well as sings. That is why, when I say choral mimesis in the title of this chapter, I mean a reenactment by way of a group that sings and dances. In the case of Sappho, as I have been arguing since 199o, her songs reveal her to be a choral personality, that is, someone who performs in a dancing as well as singing group known as a choros "chorus." ${ }^{3}$

1 See also Obbink 2014: 41.

2 See also $\S \S 156-162$ of the online version, available at https://chs.harvard.edu/CHS/article/ display/5983.

3 Nagy 2016: 456. I first used this expression choral personality in Nagy 1990: 370, with reference 
In another work on choral mimesis, centering on the Delian Maidens in the Homeric Hymn to Apollo, I emphasized the mimetic power of the chorus in performance. ${ }^{4}$ And, as I also emphasized in that work, there is an astounding variety to be found in this power of the chorus to reenact, to imitate, to represent different kinds of persons or places or things. ${ }^{5}$ In my present work, however, I limit my scope of interest to the choral character of Sappho herself in the songs that are attributed to her. Even in this limited sphere, as we will see, there is a remarkable variety of roles that are played out in the words spoken by Sappho as a prima donna who leads the choral singing and dancing.

\section{Genre and Occasion}

Now that I have contextualized the term choral mimesis in the title of this essay, I need to elaborate on my relevant use of the terms genre and occasion. In an essay I mentioned at the beginning, "Genre and Occasion" (1994-1995), I outlined the essentials of what I will now summarize here.

Of the two terms genre and occasion, the first is more problematic than the second. It would be more useful, I argued, to confront a more fundamental challenge, which is, to arrive at a definition of poetry itself in an archaic social context where the technology of writing was involved in neither the composition nor the performance of any given poem or song. Within such a context, definitions of genre have to be correlated with questions of occasion. ${ }^{6}$ And the occasion is captured, longterm, in a process that I have already described as mimesis. $^{7}$

What I just said applies to both poetry and song. I should add that, as in my earlier work, I treat poetry here as a subcategory of song and of songmaking in general. That is why, for example, I prefer to say "the Brothers Song" instead of

to Calame 1977: 367-377 (also 126-127). See also Lardinois 1996 and the remarks of Calame 2009c: 5; also Ferrari 2014: 17.

4 Nagy 2013 b.

5 In Nagy 2013b: 245-246, I give examples from the songmaking of Pindar.

6 In Nagy 1994-1995: 12, I draw attention to the perceptive use of the term occasion in Calame 1974: 116, 120, 121. In the same article, he provides a particularly useful critique of various concepts of genre in both the pre-Alexandrian and the Alexandrian eras. Important also is his assessment of Rossi 1971. To my mind, any argumentation that cites Rossi 1971 without citing Calame 1974 is incomplete.

7 Nagy 1996: 59-103. 
"the Brothers Poem" in referring to what I am about to quote and to translate. And I should also add that, as I argued already in a book published in 199o, Pindar's Homer, the term "lyric" is too broad a category to qualify as a "genre" in ancient Greek verbal art; as for "epic," this term is too imprecise and can likewise be disqualified as a "genre" - at least, with reference to the earliest attested phases of Greek songmaking. ${ }^{8}$

\section{Correlating Genre and Occasion with Composition and Performance}

In order to achieve a more accurate taxonomy of Greek songmaking in its earliest phases, two factors must be consistently kept in mind: composition and performance. Only in this way, I think, can we arrive at a basis for considering the utility of a concept such as genre - and of the related concept, occasion. ${ }^{9}$

For the moment, I define occasion as the context of performing something that is composed or precomposed. And I define genre as a set of rules that generate such a performance. ${ }^{10}$

A genre, as a set of rules that generate a given performance of a given composition, can equate itself with the occasion of performance." To this extent, the occasion is the genre. ${ }^{12}$ For example, a song of lament - that is, a song that follows the generic rules for composing and performing a lament-can equate itself with the occasion of ritually grieving for the dead. ${ }^{13}$ Moreover, if the occasion is destabilized or even lost, the genre can compensate for it, even recreate it. $^{14}$

I referred above to the act of lamentation for the dead as a ritual. I justify my use of this term here because, as is most evident in the earliest attestations of

8 Nagy 1990: 17-115.

9 Nagy 1994-1995: 12.

10 This formulation is a compressed version of what I said in Nagy 1994-1995: 13, where I also introduced the notion of performance as a speech act, as analyzed in Nagy 1990: 31. In my compressed presentation here, I force myself to make do without using the term speech act.

11 Nagy 1994-1995: 13. There but not here, I consider the factor of performance in the context of a speech act.

12 Nagy 1994-1995: 13, following Nagy 1990: 362.

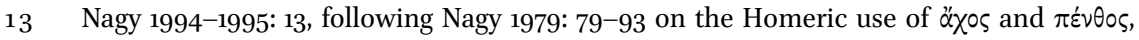
both meaning "grief," as programmatic indicators of ritual songs of lament.

14 Nagy 199o: 9, 362 n. 127. 
ancient Greek songmaking, the occasions for the performances of songs such as laments are in fact occasions of ritual. And here I understand ritual in the broadest possible sense of the term. I now offer a working definition: ritual in any given traditional society is doing things and saying things in a way that fits the cosmic order as viewed by that society. Correspondingly, I must add, myth in any given traditional society is saying things that ultimately connect with the ritual world of that society. In terms of these general working definitions of ritual and myth, ritual frames myth in traditional societies: myth is performed, and the performance is ritual. To put it another way, performance frames the composition of myth, and we cannot fully grasp the essence of such composition without knowing about its performative frame..$^{15}$

These broad definitions are meant to address the worries of experts in literature who are unfamiliar with anthropological approaches to customary events in traditional societies. Such unfamiliarity leads to a narrow understanding of ritual. It is as if ritual were confined to events that involve making direct contact with something that is overtly sacred, as in the case of sacrificing to superhuman powers. But ritual can in fact include a wide variety of events that are framed by such acts as sacrifice. The trouble is, many of these events would no longer seem to have anything to do with ritual in the narrow sense of the word as understood by the modern mind.

One such event would be the singing of a song about unrequited love in the traditional world of songmaking. To the modern mind, the act of singing such a song may seem nothing more than a form of artistic self-expression. In a traditional society, on the other hand, the singing may be framed in the context of, say, a celebration that is inaugurated by a sacrifice. Such celebrations, as we will see in the case of songs attributed to Sappho, include events like the singing of songs about unrequited love.

But what happens if the frame is lost? That is, what happens if the occasion for performing a given genre of song - like a love song — becomes obsolete? Such obsolescence seems in fact inevitable when we consider the eventual breakdown of older conventions in the history of ancient Greek song culture. So, if we face up to the historical realities, the question is most justifiable: to repeat, what happens if the occasion for performing a given genre of song becomes obsolete? My answer, as I work it out in this essay, is that there are two possible outcomes:

1. If the occasion becomes obsolete, then the corresponding genre may become obsolete as well.

15 Nagy 1994-1995: 14, following Nagy 1990: 8-9, 31-33. 
2. Even if the occasion becomes obsolete, the corresponding genre may remain current by way of compensating for the obsolescence of the occasion. And the compensation may take place by way of some alternative occasion of performance. ${ }^{16}$

In this essay, I concentrate on a historical example where both outcomes are attested, and this example involves the songmaking of Sappho.

\section{Genre and Occasion in the Songmaking of Sappho}

On the island of Lesbos around 6оовсе, which is the historical situation that leads ultimately to the texts recording the songs attributed to Sappho, the primary genre that mediated the relevant songmaking can be described as choral lyric song, and the kind of occasion that called for such song can best be described as festive performances by groups of girls and, as we will soon see, of women as well. At this point, I must emphasize again that the original Greek

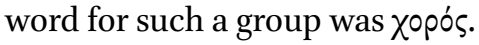

But there is more to it. In the case of Sappho, we can detect alternative kinds of occasion for performing her songs. Here I summarize briefly my relevant findings as presented in two lengthy pieces of research, published in 2007 and 2016. The 2007 piece is entitled "Did Sappho and Alcaeus ever meet?"17 As for the 2016 piece, which is chapter 21 in the Newest Sappho book, I have already referred to it at the beginning and will now refer to its title only in an abbreviated form: "A Poetics of Sisterly Affect."18

Besides the primary kind of occasion for the performing of Sappho's songs, which was the singing and dancing of female choroi "choruses," there were also secondary kinds of occasion. Already in the same era, around 6оовсЕ on Lesbos, the songs of Sappho could also be sung and danced by male performers in a kind of informal singing and dancing group known as the komos, which can be translated roughly as "a gathering of revelers." Further, these songs could even be sung monodically — that is, solo-by male performers at occasions that could be either public or private. In the case of public occasions, the monodic performers would be professional singers who competed with each other at festivals. ${ }^{19}$ Timothy Power has done important research on this kind of

\footnotetext{
16 Nagy 1994-1995: 13-14, following Nagy 199o: 9, 362.

$17 \quad$ Nagy 2007.

18 Nagy 2016.

19 I make the argument in both Nagy 2007 and Nagy 2016.
} 
public occasion. ${ }^{20}$ As for private occasions, the word for this kind of venue was sumposion or "symposium": here I single out the arguments of Ewen Bowie in chapter 6 of the 2016 Newest Sappho book, "How did Sappho's Songs get into the Male Sympotic Repertoire?"21 So we see here a variety of different occasions for performing the songs of Sappho, and all these occasions could have coexisted with each other at the same time and in the same place, that is, around 6оо BCE on the island of Lesbos. ${ }^{22}$

Of all the possible occasions for singing the songs of Sappho, however, I think only two survived beyond the original setting as dated at around 6оо вСЕ. These two kinds of occasion were the public concert and the private symposium, since the songs of Sappho kept on being performed for centuries beyond 6оо вСЕ in places like Samos and Athens by professional solo singers at public festivals and by amateur solo singers at private symposia. ${ }^{23}$ And the textual recording of Sappho's songs seems to derive from this ongoing phase of performing the songs. But the actual wording of the songs themselves, as I argue, goes back all the way to the choral lyric phase of the tradition, dating back roughly to 6оовСЕ.

\section{Diachronic Sappho}

I used the term "original setting" above in referring to the performances of female choruses on the island of Lesbos at around 6оо BCE. But this term is for me inadequate, since my own reconstruction of such performances depends on a diachronic perspective, which I combine with a synchronic perspective in analyzing the texts reflecting the songmaking attributed to Sappho. The terms synchronic and diachronic, as I use them here, come from linguistics. ${ }^{24}$ When linguists use the word synchronic, they are thinking of a given system or structure as it exists in a given time and space; when they use diachronic, they are thinking of that system as it evolves through time. I must add that a historical perspective is not the same thing as a diachronic perspective:

\footnotetext{
20 On singing to the accompaniment of the kithara in monodically performing the songs of Sappho, see Power 2010: 258-263, followed by Nagy 2011c: $155^{-1} 5^{8}$.

21 In chapter 17 of the same book, Renate Schlesier argues that the performers of Sappho's songs at symposia could be courtesans (Schlesier 2016).

22 Again, Nagy 2007, 2015.

23 Nagy 2007.

24 See Nagy 2011b §11, with reference to Saussure 1972: 117.
} 
Both synchronic and diachronic perspectives are a matter of model building. We can build synchronic models to describe and explain the workings of a structure as we see it attested in a given historical context. We can likewise build diachronic models to describe and explain how that given structure may have evolved from one of its phases into other phases. What we have built, however, is a set of models to be tested on historical realities. The models are not the same thing as the realities themselves. And the realities of history as a process are not dependent on such models. History may either confirm or upset any or all aspects of our models, since the contingencies of history do not need to follow the rules of existing structures. ${ }^{25}$

From a diachronic perspective, the system that we know as Sappho's poetics can be viewed, I argue, as an evolving medium. So, when I say "diachronic Sappho" in the title of this section, I am referring to a model of a poetic system as I reconstruct it through time. By contrast, when we speak of a "historical Sappho," we are imagining the existence of a person who lived in a historically identifiable era. I say "imagining" because for me the existence of such a historical person is not at all proven to be a fact if we rely simply on the words that are attributed to Sappho in the texts ascribed to her. What she says about herself and about anyone and anything else in her songs is a function of her songmaking: it is not some kind of reportage about her historical circumstances. In terms of my argument, the words of Sappho can be used as evidence for understanding the history of the songmaking attributed to her, but I insist that whatever the persona of Sappho says about herself cannot be used as factual evidence about the life and times of Sappho.

\section{A Diachronic View of Sappho's Occasions}

From a diachronic point of view, the earliest transmission of Sappho's songmaking depended on an ongoing tradition of performing her songs in a setting that corresponded to a primary occasion, which was the choral lyric singing and dancing of girls and even of women at festive events. In the two lengthy pieces of mine that I mentioned above, "Did Sappho and Alcaeus ever meet" and "A Poetics of Sisterly Affect," I explored in some detail the historical evidence for identifying a location for such a primary occasion, which was a sacred precinct

$25 \quad$ Nagy $2011 b$ § 16. 
located in the middle of the island of Lesbos. The ancient Greek name for this precinct was Messon, meaning "middle place," and this name survives in Modern Greek as Mesa, referring to the very same place that had once been a venue, as I see it, for the songs of Sappho-and even of Alcaeus.

Festive choral lyric performance, as the primary genre for Sappho's songs, was also the primary occasion for these songs. Further, this occasion is captured, longterm, in the process of mimesis.

\section{An Occasion for a Song of Sappho}

Here I return to the work of Leslie Kurke on the Brothers Song of Sappho in chapter 11 of the 2016 Newest Sappho book. As I noted from the start, Kurke thinks that the woman who is being addressed by the speaking persona of Sappho in this song is the mother of Sappho. She points to the fact that Martin West, in his reconstruction of Song 9 of Sappho by way of a new papyrus fragment, thinks that this other song, which features the speaker addressing someone as "mother," immediately preceded the Brothers Song in the textual tradition of Sappho's collected songs. ${ }^{26}$ I quote here only the relevant wording of the new Sappho fragment: ${ }^{27}$

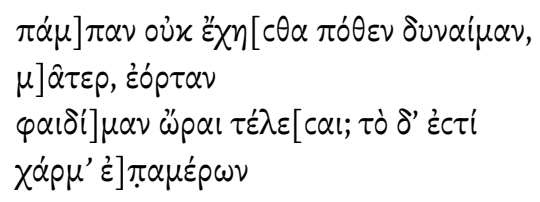

... Don't you have the resources for me to be able, Mother, to celebrate [telein] at the right season [ōrā] the festival [eortā], which is a delight [charma] for [us] mortals, creatures of the day that we are?

SAPPHO fr. 9. $2-5$

In terms of Kurke's argument, Sappho here is speaking to her mother on the occasion of a festival that she desires to celebrate. As I infer from the wording of this fragment, the occasion for any given song of Sappho may at times be a festival, and the genre of such a festive song is normally choral singing and dancing. In what follows, I will try to link the terms choral and mimesis as featured in the title of my essay.

26 West 2014: 7 .

27 I follow here the text as restored by West 2014. But the translation is my own. 
Kurke thinks that Sappho is speaking to her mother not only here in Song 9 but also in the Brothers Song. Let me now quote for you the surviving part of the Brothers Song:

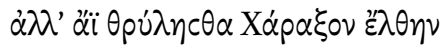

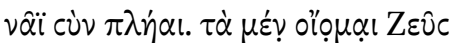

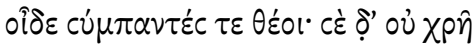
$\tau \alpha \hat{\tau} \tau$ vónc $\theta \alpha \mathrm{l}$,

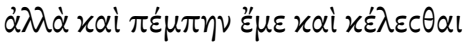

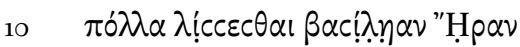

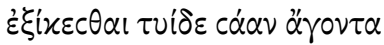
$\nu \hat{\alpha} \alpha \mathrm{X} \alpha \dot{p} \alpha \xi o v$

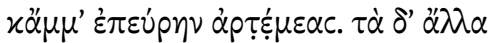

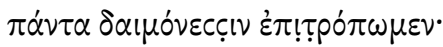

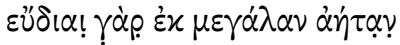

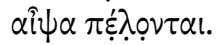

$\tau \omega \hat{\nu} x \varepsilon \beta \dot{o} \lambda \lambda \eta \tau \alpha l \beta \alpha c^{\prime} \lambda \varepsilon u c^{\prime} \mathrm{O} \lambda \dot{\nu} \mu \pi \omega$

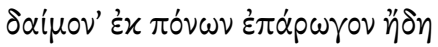

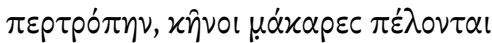

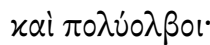

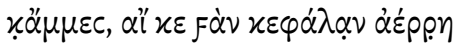

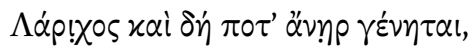

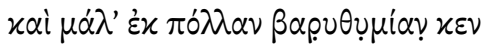
$\alpha i \psi \alpha \lambda \dot{\theta} \theta \varepsilon \iota \mu \varepsilon v$.

But you are always saying, in a chattering way [thrulein], that Charaxos will come in a ship full of goods. These things I think Zeus knows, and so also do all the gods. But you shouldn't have these things on your mind.

Instead, send [pempein] me off and instruct [kelesthai] me to implore [lissesthai] Queen Hera over and over again [polla] that he should come back here [tuide] bringing back [agein] safely his ship, I mean Charaxos, 
and that he should find us unharmed. As for everything else, let us leave it to the superhuman powers [daimones], since bright skies after great storms can happen quickly.

Those mortals, whoever they are, whom the king of Olympus wishes to rescue from their pains [ponoi] by sending as a long-awaited helper a superhuman force [daimōn]

to steer them away from such pains - those mortals are blessed [makares] and have great bliss [olbos].

We too, if he ever gets to lift his head up high, I mean, Larichos, and finally mans up, will get past the many cares that weigh heavily on our heart, breaking free from them just as quickly. SAPPHO, Brothers Song

In this song, as in the fragment from the other song I quoted, Sappho Song 9, we read about a festival. As we saw also in Sappho Song 9, the word for such a festival is eorta. As for the Brothers Song, there is a corresponding reference to a festival, expressed by way of the word pempein "send," which is a terminus technicus, as Kurke calls it, for the idea of organizing a sacred procession that culminates in a festival that is celebrated at the precinct of a divinity. In this case, the festival is sacred to Hera, and Sappho is pictured as readying herself to lead a procession that will be heading off for the festival. Kurke refers to my chapter in the same volume, where I make the argument about the word pempein as such a terminus technicus. ${ }^{28}$ Comparing a passage from the Electra of Euripides with reference to the festival of Hera at Argos (vv. 167-174), I argue that the Brothers Song features the speaking persona of Sappho as a choral leader who wishes to be sent in a procession to the sacred precinct at Messon, where a festival of the goddess Hera will be celebrated, just as the same speaking persona of Sappho in Song 9 had wished that her mother should find the means for her to celebrate this festival. ${ }^{29}$ We see here a validation of a formula proposed by Anton Bierl concerning processions as represented in Greek theater: he argues that any procession that leads into a choral performance will thereby become part of the choral performance. ${ }^{30}$

\footnotetext{
28 Nagy 2016: 459 .

29 Nagy 2016: 460-461.

30 Bierl 2009: 57 n. 152, 107, 272-273, 284, 294-295, 318-319. See also Bierl 2011.
} 
The choral essence of the performance that is represented in the Brothers Song is likewise evident in another song of Sappho that has now been supplemented by the newly-found fragments:

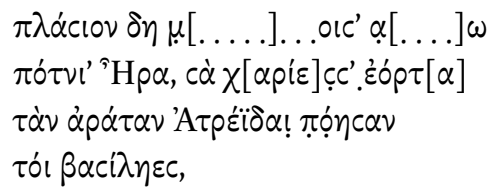

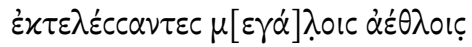
$\pi \rho \hat{\omega} \tau \alpha \mu \dot{\varepsilon} \nu \pi \dot{\varepsilon} \rho \mathrm{E}^{\prime}\left[\lambda \lambda_{10 \nu}\right] \cdot \ddot{\alpha} \psi \varepsilon \rho \rho \nu \delta \xi$

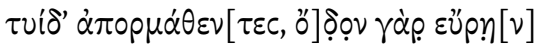

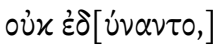

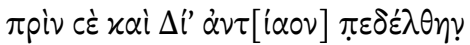

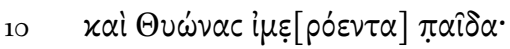
vôv $\delta \dot{\varepsilon} x[\alpha i ́ \ldots . . . . .].] \ldots \pi o ́ \eta \mu \varepsilon v$ $x \dot{\alpha} \tau \tau \dot{\partial} \pi \dot{\alpha} \lambda[\alpha ı v$

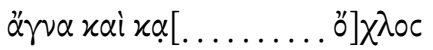
$\pi \alpha p \theta \varepsilon \dot{\varepsilon}[\nu \omega \nu \ldots . . . \ldots . \gamma] u v \alpha i x \omega \nu$

Close by, ....,

O Queen [ potnia] Hera, ... your ... festival [eortā], which, vowed-in-prayer [arâsthai], the Sons of Atreus did arrange [poiein ] for $y o u,{ }^{32}$ kings that they were,

5 after first having completed [ektelein] great labors [aethloi], around Troy, and, next [apseron], after having set forth to come here [tuide], since finding the way was not possible for them

31 On the restoration of this line, I follow Ferrari 2014: 18. Otherwise I mostly follow Obbink 2016a.

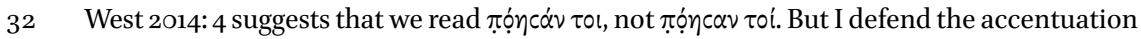

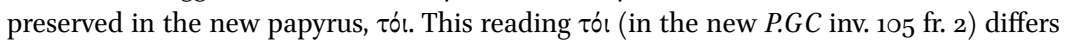
from the reading $\tau$ ol (PSI 123 and POxy. 1231). As I argue, we see here an emphatic use of the pronoun, "for you," not an enclitic use. 
until they would approach you (Hera) and Zeus lord of suppliants

[antiaos]

and (Dionysus) the lovely son of Thyone.

And now [nun de] we are arranging [poiein] [the festival],

in accordance with the ancient way ...

holy $[$ agna $]$ and ... a throng [okhlos]

of girls [parthenoi] ... and women [gunaikes]

15

on either side ...

the measured sound of ululation [ololūgā] .

SAPPHO fr. 17.1-16

Here it is made explicit that the festival in progress, while the speaker is represented as speaking, is in honor of the goddess Hera. Here is the way I describe it in chapter 21 of the Newest Sappho book, "A Poetics of Sisterly Affect":

Although the first line of Song 17 here is too fragmentary to be understood for sure, the next line makes it clear that the persona of Sappho is praying to Hera herself, speaking to her about the eortā "festival" (2: Éóp $\tau[\alpha])$ that is being arranged in honor of the goddess. The speaking Sappho goes on to say that the festival that "we" in the present are arranging (11: $\pi \dot{\eta} \eta \mu \varepsilon v)$, as "we" offer supplications to Hera, is being arranged

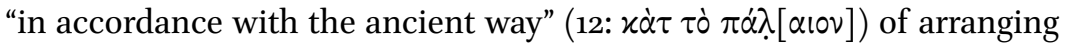
the festival, just as the heroes of the past had arranged it (3: $\pi$ óncav). In these contexts, I am translating the word poiein "make" in the specific sense of "arrange," with reference to the observance of a ritual. I find in Thucydides (2.15.2) a striking parallel in wording: "and the Athenians, continuing what he [= Theseus] started, even now arrange [poieîn] for the goddess [= Athena], at public expense, the festival [heortē] named the

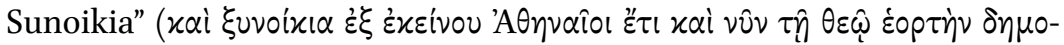
$\tau \varepsilon \lambda \hat{\eta} \pi 010 \hat{c}(\mathrm{v})$.

Comparing these three songs, I now highlight the significance of the word ora (hora) in Sappho Song 9. As I have argued in another project, hora in the sense of "season, seasonal recurrence" is linguistically and even thematically related to Hera, which is the name for the goddess of seasons. ${ }^{33}$ So, the use of the word ora (hora) in Song 9 points to Hera as the honorand of the eorta (heorte). 
Now I return to the relevant wording in the Brothers Song (5-7): $\pi \dot{\varepsilon} \mu \pi \eta \nu$

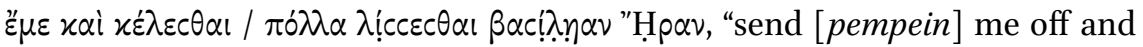
instruct [kelesthai] me / to implore [lissesthai] Queen Hera over and over again [polla]." I understand such an act of instructing someone to do something as a choral act, and I interpret the relation between the instructor and the instructee as a choral relationship between the mother as a woman and the daughter as a girl. The woman chorally authorizes the girl. And such a choral relationship is formalized in the distinction between gunaikes "women" and parthenoi "girls" at the end of Song 17 of Sappho. This song refers explicitly to a choral performance at the sacred precinct of the goddess Hera on the occasion of her festival, which is called an eorta. As I argued in "A Poetics of Sisterly Affect," the occasion of Song 17 marks the performance of Sappho herself as the prima donna who leads the choral singing and dancing at the festival of Hera. As the prima donna, she is the main celebrant, as marked by the programmatic use of the verb poiein at line 11 of this song in the sense of "celebrate a festival."

In the Brothers Song, then, if Kurke is right, there is a mother involved. And then there are the brothers. In this Brothers Song, the brother called Charaxos is mentioned by name, and so too is another brother called Larichos. And then there is also another song where one of the two brothers is mentioned without being named, and it must be Charaxos. Here is the relevant part of the song:

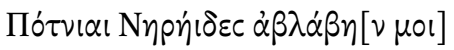

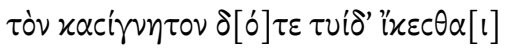

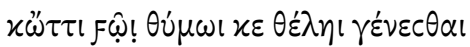

$$
\begin{aligned}
& x \eta \hat{\nu} \sim \tau \varepsilon \lambda \varepsilon \dot{c} c \theta \eta \text {, }
\end{aligned}
$$

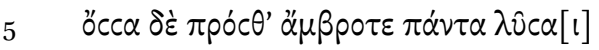

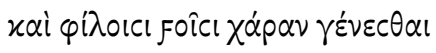

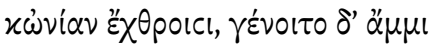

$$
\begin{aligned}
& \mu \eta \delta \alpha^{\prime} \mu \alpha \mu \eta \delta^{\prime} \text { हic. }
\end{aligned}
$$

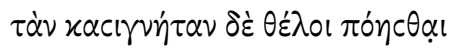

O Queen Nereids, unharmed [ablabēs] may my brother, please grant it, arrive to me here [tuide], and whatever thing he wants in his heart [thümos] to happen, let that thing be fulfilled [telesthēn]. 
5 And however many mistakes he made in the past, undo them all. Let him become a joy $[k h a r a \bar{a}]$ to those who are near-and-dear [philoi] to him, and let him be a pain [oniā] to those who are enemies [ekhthroi]. As for us, may we have no enemies, not a single one.

But may he wish to make his sister [kasignètā] 10 worthy of more honor [timmā]. The catastrophic [lugrā ] pain $[$ oniā $]$ ... in the past, he was feeling sorrow [akheuōn $]$... SAPPHO fr. $5 \cdot 1-11^{34}$

Here I recapitulate what I said in chapter 21 of the Newest Sappho book. ${ }^{35}$ I start with the fact that the loving sister in Song 5 is expressing a wish that her errant

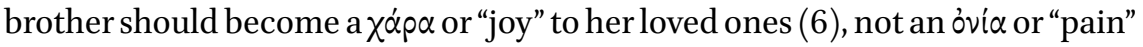
(7) - a pain that is then described as $\lambda$ vypó "catastrophic" (10). ${ }^{36}$ It should be the other way around, she is saying, so that the family will have the joy — while the enemies will have the pain.

Later on in Song 5 , the speaking persona of Sappho turns to Aphrodite,

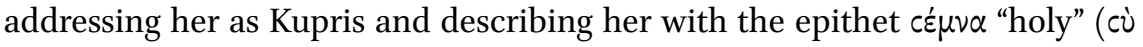
$[\delta] \grave{c}$ Kú $\pi[\rho] ! ఢ[\varepsilon \dot{\varepsilon} \mu] \nu \alpha, 18)$. Although the fragmentary state of the papyrus here prevents us from seeing the full context, it is clear that the sister is praying to the goddess to prevent further misfortune from happening to her brother, who "in the past was feeling sorrow" ( $\left.\pi[\dot{\alpha}] \rho \circ \theta \theta^{\prime} \dot{\alpha} \chi \varepsilon \dot{v} \omega \nu, 11\right)$.

But the pain that torments the family because of the brother's misfortunes is not the only kind of torment we find in the poetics of Sappho. The same word ovia "pain" that refers to the torment experienced by the family of Sappho refers also to the torment of erotic love experienced by Sappho herself. In Song 1 of Sappho, her speaking persona prays to Aphrodite to release her from such torment:

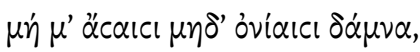
$\pi o^{\tau} \tau \nu \alpha, \theta \hat{\nu} \mu \nu$

34 For the text here, I generally follow what is printed in Obbink 2016a, though I occasionally commit to one of two possible readings considered by the editor, as at line 11 .

35 Nagy 2016: $45^{\circ}-45^{2}$.

36 It is possible, of course, that [ov] $\alpha \alpha v$... $\lambda v^{\prime} \gamma p \alpha \nu$ is a genitive plural, not an accusative singular. 
Do not dominate with hurts [asai] and pains [oniai],

O Queen [potnia], my heart [thümos].

SAPPHO fr. 1.3-4

Similarly in the first six lines of the Kupris Song the speaking persona of Sappho once again turns to Aphrodite, that is, to Kupris, and she prays yet again that the goddess may release her from the torment of an erotic love that is quite unrequited:

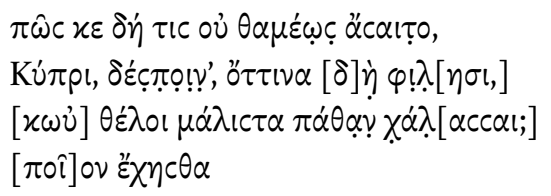

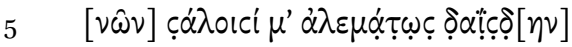

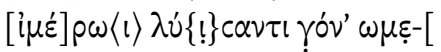

How can someone not be hurt [asasthai, verb of the noun asa "hurt"] over and over again,

O Queen Kupris [Aphrodite], whenever one loves [philein] whatever person

and wishes very much not to let go of the passion?

[What kind of purpose] do you have

5 [in mind], uncaringly rending me apart

in my [desire] as my knees buckle?

SAPPHO, Kupris Song 1-6

The ending of this song was already known before the discovery of the new supplements for the beginning as I just quoted it. At this ending, we find the persona of Sappho declaring the poetics of her own self-awareness:

...है $\gamma \omega \delta^{\prime}$ ' है $\mu^{\prime} \alpha{ }^{\prime} \tau \alpha l$

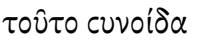

And I-aware of my own self-

I know this.

SAPPHO fr. 26.11-12

We have just seen, then, some powerful examples of singing about unrequited love. To the modern mind, as I said at the beginning of this essay, the act 
of singing such songs may seem nothing more than a form of artistic selfexpression. But we can see from comparing these texts with each other that the medium for expressing the emotions in such songs is in fact choral.

\section{Rethinking Mimesis}

As I have already argued, mimesis involved primarily reenactment and secondarily imitation. ${ }^{37}$ But now I rethink the formulation:

If you re-enact an archetypal action in ritual, it only stands to reason that you have to imitate those who re-enacted before you and who served as your immediate models. But the ultimate model is still the archetypal action or figure that you are re-enacting in ritual, which is coextensive with the whole line of imitators who re-enact the way in which their ultimate model acted, each imitating each one's predecessor. ${ }^{38}$

When it is your turn, your moment to reenact something in this forward movement of mimesis, you become the ultimate model in that very moment. As a way of understanding occasion, then, I propose to equate it with the moment of mimesis. ${ }^{39}$

Things started changing, however, by the middle of the fifth century вСЕ. Ву now the primary meaning of mimesis as "reenactment" was becoming lost or at least destabilized, and the secondary meaning was encroaching on the primary meaning. ${ }^{40}$

My interpretation of mimesis as an authoritative "reenactment, impersonation" is supported by the celebrated description of mimesis in the Poetics of Aristotle as the mental process of identifying the representing "this," as in the ritual of acting a drama, with the represented "that," as in the myth that is being acted out by a drama: in Greek this mental process can be expressed by way

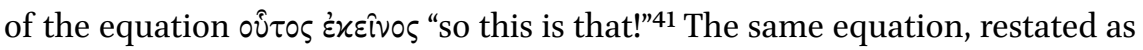

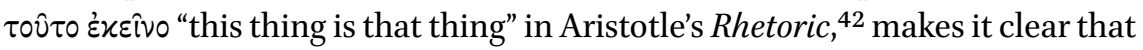
the media of representation that Aristotle has in mind are not just the visual

37 See further Nagy 1994-1995: 14; also already 1990: 42-44, 373-375, especially 42 n. 125 .

38 Nagy 1996: 56.

39 Nagy 1994-1995: 15.

40 Nagy 1990: 339-381, taking into account the acute observations of Nehamas 1982.

41 Arist. Poet. 1448b17. Nagy 199o: 44.

42 Arist. Rh. 1371b9. 
arts but also the verbal arts, primarily the art of songmaking and poetry as performed in drama. ${ }^{43}$ So long as the represented "that" remains absolute - that is, absolutized by the myth - the representing "this" remains a reenacting "this." 4 So long as "this" imitates an absolute "that," it reenacts as it imitates; the reenactment remains primary, and the imitation remains secondary. ${ }^{45}$ Once you start imitating something that is no longer absolute, however, you can no longer reenact the absolute: then you can only make a copy, and your model may be also just a copy. I have just described here the general mentality induced by the destabilization of the conceptual world of mimesis. ${ }^{46}$

Earlier, I made the claim that genre can compensate for the occasion. But now, applying the semantics of mimesis, I extend the argument by claiming that genre can even absolutize the occasion. A striking example is the "epinician moment" as dramatized in the epinician songs ("victory odes") of Pindar. ${ }^{47}$ Seth Schein has analyzed Pindar's Pythian 6 as an illustration of that moment, ${ }^{48}$ and he quotes in this context the remarks of Hans-Georg Gadamer, who has this to say about the element of the occasional in the epinician songs of Pindar:

The occasional in such works has acquired so permanent a form that, even without being realised or understood, it is still part of the total meaning. Someone might explain to us the particular historical context, but this would be only secondary for the poem as a whole. He would only be filling out the meaning that exists in the poem itself.49

With this formulation in mind, I tried to rethink the essentials of Pindaric songmaking in my 1994 essay "Genre and Occasion." I argued that any given Pindaric composition defies the realization of all the signs of occasionality that it gives out about itself. This defiance is not the result of any failure to adhere to the given occasion of real performance. Rather, it is a mark of success in retaining aspects of occasionality that extend through time. If we think of occasion as a performative frame, even a ritual frame, then what we see in a Pindaric composition is an absolutized occasion. Moreover, this occasion is absolutized by deriving from the diachrony of countless previous occasions. In other words,

\footnotetext{
43 Nagy 1994-1995: 15-16.

44 Nagy 1990: 42-44.

45 Nagy 1994-1995: 16, following Nagy 1990: 42-44. See also Nagy 1996: $55^{-56}$.

46 Cf. Nehamas 1982.

47 Nagy 1990: 381.

48 Schein 1987: 246-247.

49 Gadamer 1975: 129.
} 
a Pindaric composition refers to itself as an absolute occasion that cannot be duplicated by any single actual occasion. Only an open-ended series of actual occasions, occurring in a continuum of time, could provide all the features of an absolutized occasion. ${ }^{50}$

\section{Occasions for the Songs of Sappho}

I now turn from the occasions for the songmaking of Pindar, as sketched in my essay "Genre and Occasion," to occasions for the songmaking of Sappho. As the title for my current essay indicates, where I speak of choral mimesis, I am concentrating here on choral occasions for Sappho's songmaking, not on monodic occasions, which would be appropriate for concerts featuring professional male singers or for symposia featuring amateur male singers. And the primary occasion for a choral performance would be a festival, the word for

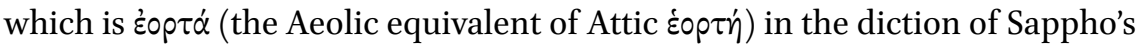
songmaking. We see the word in line 3 of Song 9 and in line 2 of Song 17 .

In the discursive framework of a chorus, what Sappho says when she speaks by way of choral song is not simply some kind of reportage about her historical life and times. What she says, rather, is a mimesis of situations as sung and danced by a chorus led by a prima donna. Such situations are exemplified, as we have seen, by choral songs about unrequited love. And the choral mimesis is not only the act of talking about persons in the third person, thus representing those persons, such as the two brothers named Charaxos and Larichos in the Brothers Song. Nor is it only the act of addressing persons in the second person, thus also representing those persons, such as the mother in Song 9. It is also the act of representing a person even in the first person, and this represented person does not have to be the same person as the representing performers who say "I" or "we" when they perform in the chorus.

Choral performance at a festival is not some ad hoc event. It is a seasonally recurring event, celebrated in honor of the god or goddess whose sacred precinct is the venue for the celebration. But this is not to say that the chorus sings and dances only about the festival. True, the chorus can sing and dance about its own context by referring to the festival, as we see in Song 17 , for example, but it can also sing about anything and everything that can happen to any persons in the third person or to the addressees in the second person or even to the self, who can be pictured as the main speaker, that is, as the prima donna

50 Nagy 1994-1995: 18-19. 
of the singing and the dancing of the chorus. The things that happen, however, do not have to be things that are being experienced then and there in the context of the performance. The things that happen do not even have to be things experienced in the past by the choral persons who are speaking in the first person as they sing and dance their song. The experiences may belong primarily to the persons who figure in the mimetic world of the song that is being sung and danced and only secondarily to the persons who perform the song in the here and now of the festival.

This formulation, I argue, can apply to choral performance not only on the occasion of seasonally recurring festivals but also on the occasion of ad hoc events like laments performed at funerals or love songs performed at weddings. On such occasions as well, choral mimesis can allow for the modeling of identities on preexisting identities. In this essay, however, I concentrated on the seasonally recurring event of a festival held at the sacred precinct of Messon, as described by the words of Sappho in Song 17 .

In terms of my overall argument, moreover, the Brothers Song likewise has as its occasion the sacred precinct of Messon. Here we see the persona of a sister who is singing about her experiencing $\pi$ óvor "pains" (line 18) caused by two brothers named Charaxos and Larichos. In the case of the second brother to be mentioned, Larichos (line 22), the sister is upset that the brother cannot seem to achieve adulthood: he fails to "man up" (line 22). That is the pain. In the case of the first brother to be mentioned, Charaxos (lines 5, 12), the pain that he causes can be reconstructed by combining the references here in the Brothers Song with references in other songs of Sappho, and I am convinced that these references add up to a story about a disastrous love affair that depletes the wealth of the whole family. As we reconstruct the story, Charaxos has fallen in love with a courtesan from Naucratis whose name in the songs of Sappho is Doricha.

These three names, Doricha and Larichos and Charaxos, can all be explained in terms of generic namings, much as the name of Sappho herself can be explained as generically meaning "sister." In chapter 4 of the Newest Sappho book, "Sappho, Iambist: Abusing the Brother," Richard P. Martin argues persuasively that Doricha means something like "tiny little gift," derived from doron "gift." Such a meaning, combined with a diminutive suffix like -icha, would produce a fitting name for a courtesan or prostitute. Similarly, I would argue that Larichos is a diminutive name derived from the adjective laros, which in Odyssey 2.35 is associated with the delicious taste of wine. ${ }^{51}$ It is as if the name

$5^{1} \quad$ I think that the long $a$ of laros in Homeric diction results from a kind of innovative poetic lengthening: see Nagy 2008: 34-35. 
of this brother meant something like "tiny little delicacy."52 Such an interpretation can supplement, I think, the argumentation of André Lardinois in chapter 7 of the Newest Sappho book. He highlights the testimony of Athenaeus, who

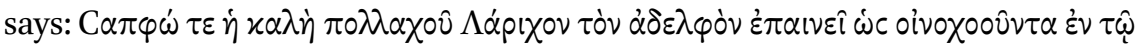

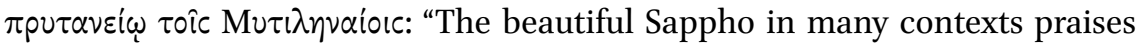
her brother Larichos, because he poured the wine for the Mytilenaeans in their

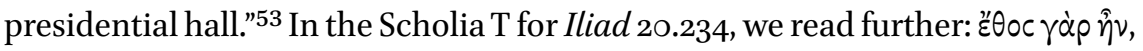

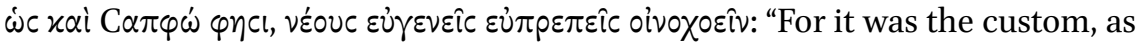
even Sappho says, for good-looking young aristocrats to serve as wine-pourers." And then there is Charaxos, which I think is a diminutive name derived from the noun $\chi \alpha \rho \alpha$ "delight, joy." We have seen this word $\chi \alpha$ pó in line 6 of Song 5 , where the voice of Sappho wishes that Charaxos become a "joy" to her and to the whole family. It is as if the name of Charaxos were a wish-fulfillment for the sister who has experienced so much pain in worrying about her errant brother. And here we may consider also the festive context of $\chi \alpha \rho \dot{\alpha}$ "delight" in Song 9 . So, Charaxos is the would-be "tiny little joy" or "tiny little delight" for the family. This theme seems to be picked up by the poet Posidippus when he describes

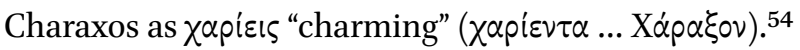

To talk this way about your brothers is a sisterly thing to do. And the intimacy of such talk, replete with diminutives, can be imitated in choral song. Such talk can sound like baby talk, and I think that the verb $\theta p u \lambda \varepsilon i v$, which is conventionally translated as "chatter," can refer to such baby talk. As I argued in "A Poetics of Sisterly Affect," even the name of Sappho conveys the impression of such baby-talk as imitated in the mimetic performances of female choruses. ${ }^{55}$ I find it significant that Electra in the Euripidean drama that is named after her uses this word $\theta p u \lambda \varepsilon i v$ at line 910 when she tells her brother Orestes about her strong desire to "chatter" on and on to him about all the things she has experienced since the separation of these two siblings. And such talk is not just sisterly talk: it can also be motherly talk, as imitated in choral song. That is the sense of

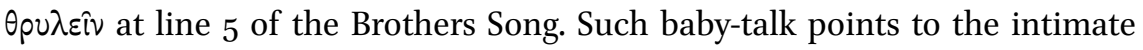
conversations that can take place between mothers and daughters, between women and girls, in choral performance.

52 In chapter 14 of the 2016 New Sappho book, "'All you Need is Love': Some Thoughts on the Structure, Texture, and Meaning of the Brothers Song as well as on Its Relation to the Kypris Song (P. Sapph. Obbink)," Anton Bierl has already drawn attention to the association of Larichos with the adjective laros.

53 Ath. 10.425a.

54 Posidippus $122 \mathrm{AB}$, line 2, quoted in Ath. 13.596c. On this association of Charaxos and $\chi \alpha \mathrm{pi}^{-}$ हıৎ "charming," see also Burris, Fish, and Obbink 2014: 24.

55 Nagy 2016: 489-491. 
Such relationships-between mother and daughter, between sister and brothers-are not "fictional" in the songs of Sappho. But they are not "historical," either. Rather, such relationships are simply mimetic. To speak of a "fictional" or a "biographical" relationship, either way, is to set up a false dichotomy. And the same goes for the idea of a "fictional" or a "biographical" Sappho. All these personae are primarily mimetic, and their occasion is what happens by way of choral performance. The crisis of worrying over an errant brother-or of suffering from an unrequited love-is not the occasion for choral performance. The occasion is the mimesis of such emotional crises. And such occasions can happen at festivals, even if such festivals take place only once every year.

\section{A Second Lesley}

Here I finally arrive at a point where I can introduce the second Lesley to whom I dedicate this essay. She is Lesley Gore, who recorded in 1963 a song that became wildly popular and stayed that way for a long time. The title of the song is "It's My Party." Gore is pictured on the album cover, a girl wearing a mischievous half-smile. Her looks in this picture do not match the feelings that she is singing about in her song, which is all about crying — crying about unrequited love.

It's my party and I'll cry if I want to

Cry if I want to

Cry if I want to

You would cry too, if it happened to you

Nobody knows where my Johnny has gone

But Judy left the same time

Why was he holding her hand

When he's supposed to be mine?

It's my party and I'll cry if I want to

Cry if I want to

Cry if I want to

You would cry too, if it happened to you

Play all my records, keep dancing all night

But leave me alone for awhile 
Till Johnny's dancing with me

I've got no reason to smile

It's my party and I'll cry if I want to

Cry if I want to

Cry if I want to

You would cry too, if it happened to you

Judy and Johnny just walked through the door

Like a queen with her king

$\mathrm{Oh}$, what a birthday surprise

Judy's wearing his ring

It's my party and I'll cry if I want to

Cry if I want to

Cry if I want to

You would cry too, if it happened to you

Oh, it's my party and I'll cry if I want to

I like to compare this song about an emotional crisis with some songs attributed to Sappho, who dates all the way back to 6оо вСE or thereabouts. My favorite part of the song sung by Lesley Gore is where the singer tells her listeners that she doesn't mind if they play all her records all night, dancing all the while to the music of the song, but she wants to be left alone for a while, because she has no reason to smile. Back then in 1963 , records would be played at occasions like birthday parties, and young people could indeed dance all night long to the songs that were sung on the records. But the occasion for the singing recorded on records is not the sadness of a lonely speaker who sings about unrequited love. Rather, the occasion is the performance of her song as a recorded double-track for a vinyl disk that makes 45 revolutions per minute every time the song is played on the record-player. And, as the record gets played and replayed over and over again, the sadness of the girl who is pictured in the song recurs over and over again. So also the singer in the songs of Sappho implores Aphrodite over and over again to free her from the sadness of unrequited love, or she prays to Hera over and over again to make things all better for her family and thus ease her anxieties. Each time a chorus sings and dances her songs, the sadness and the worries recur. And the occasion is the mimesis of these emotions by way of song and dance. The emotions themselves are not the occasion. 
For all we know, the occasion for such singing could be a yearly festival, where the song could get performed and reperformed every year, over and over again, just as the sadness of the girl who is pictured in the song recurs over and over again. But that will not stop the singer from wearing a mischievous halfsmile.

As the blues singer Rubin Lacy once said, you don't have to have the blues to sing the blues:

I've sung 'em on many a day and never thought I had 'em. What did I want to have the blues for, when I had everything I wanted, all the liquor, all the money I needed, and more gals than I needed? What did I need with the blues? I was playin' 'em because everybody loved to hear me play 'em and I loved to play 'em. I could play 'em, yeah. ${ }^{56}$

$5^{6}$ Quoted in Evans 1982: 112. Thanks to Adam Holland. See also Nagy 2004: 48. 